\title{
Cum privilegio: Licensing of the Press Act of 1662
}

\section{Citation}

Nipps, Karen. 2014. “Cum Privilegio: Licensing of the Press Act of 1662." The Library Quarterly: Information, Community, Policy 84 (4) (October): 494-500. doi:10.1086/677787.

\section{Published Version}

doi:10.1086/677787

\section{Permanent link}

http://nrs.harvard.edu/urn-3:HUL.InstRepos:17219056

\section{Terms of Use}

This article was downloaded from Harvard University's DASH repository, and is made available under the terms and conditions applicable to Other Posted Material, as set forth at http:// nrs.harvard.edu/urn-3:HUL.InstRepos:dash.current.terms-of-use\#LAA

\section{Share Your Story}

The Harvard community has made this article openly available.

Please share how this access benefits you. Submit a story.

Accessibility 


\section{Cum privilegio: Licensing of the Press Act of 1662}

opyright has troubled humans for almost as long as our thoughts have been recorded. The ancient Greeks, Jews, and Romans all set down laws concerning an author's personal rights, a sponsor/publisher's economic rights, an owner's rights to an individual copy, and a ruler's right to censor and to regulate the industry. The Church and various governments (both totalitarian and democratic) have tried copyrighting any number of times. We are still at it today. As of the writing of this piece, currently pending in Washington is legislation that some have referred to as "the next great copyright act" (Pallante 2013). This act-if it ever comes to pass - will have the American government ruling on procedures regarding such varied property as orphan works, musical recordings, film, and fashion design, particularly as they relate to digitization and the Internet. As Maria A. Pallante, register of copyrights of the United States and director of the US Copyright Office, has explained the act, "It must confirm and rationalize certain fundamental aspects of the law, including the ability of authors and their licensees to control and exploit their creative works, whether content is distributed on the street or streamed from the cloud. And it must provide sufficient clarity to those who seek to use protected works" (Pallante 2013, 324).

One of the most influential documents in the history of Anglo-American copyright is the Licensing of the Press Act of 1662-mostly for its negative effects (fig. 1). Charles II had returned to the English throne in 1660 and was appalled at the state of printing in his realm. Seditious, irreligious, pernicious, and scandalous books and pamphlets flooded the streets of London (among them the works of Milton and Hobbes). In order to censor the unruly, this king had Parliament enact "An Act for preventing the frequent Abuses in printing seditious treasonable and unlicensed Bookes and Pamphlets and for regulating of Printing and Printing Presses" (Licensing of the Press Act, 1662, 14 Car. II, c. 33; also see Deazley 2008a). It achieved its stated purpose with a variety of provisions, almost all of them reenactments of similar provisions in an order of the Star Chamber of 1637 (which itself was preceded by other

Library Quarterly: Information, Community, Policy, vol. 84, no. 4, pp. 494-500. (C) 2014 by The University of Chicago. All rights reserved. $0024-2519 / 2014 / 8404-0012 \$ 10.00$ 


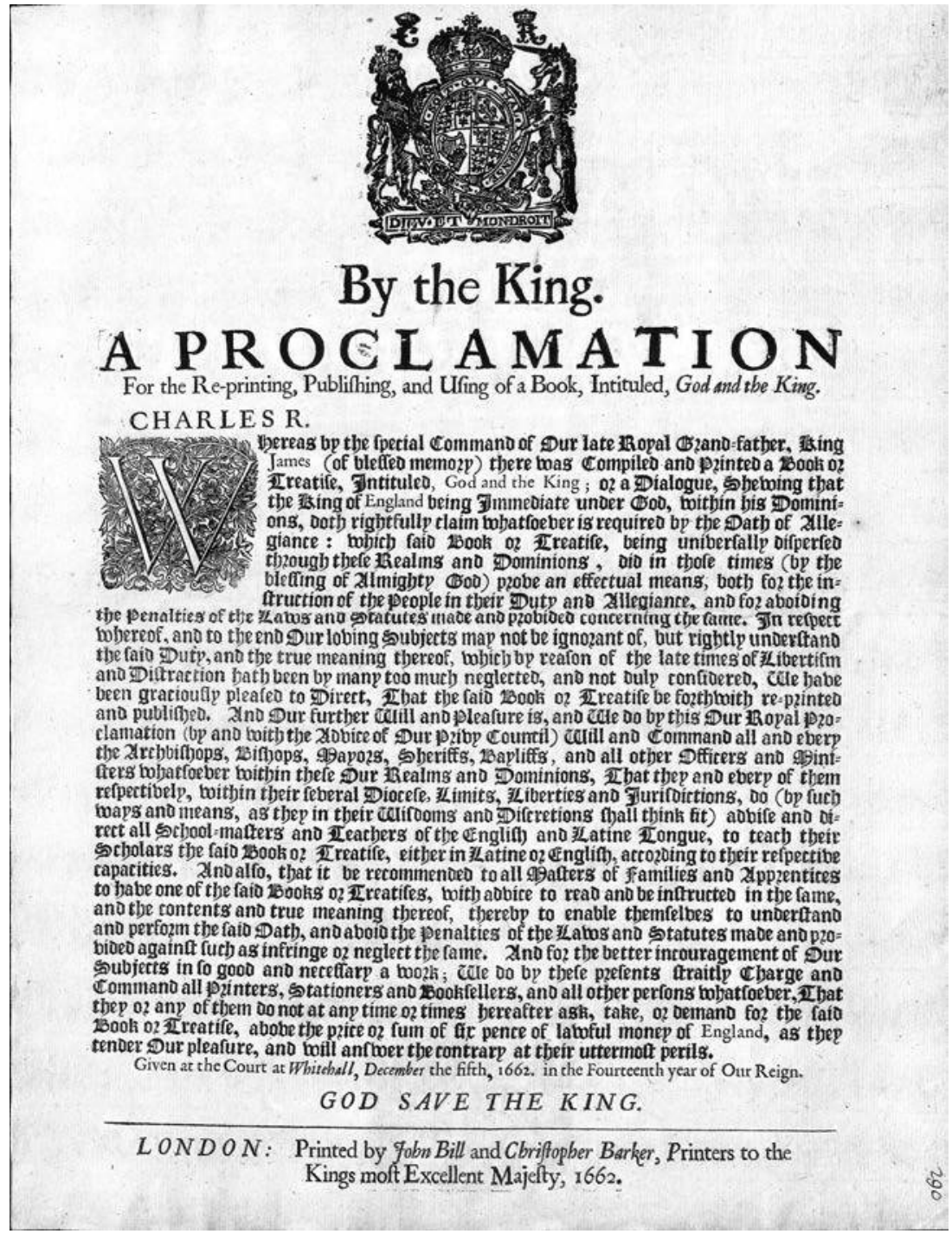

Figure 1. One of the many bills issued on the heels of the Licensing Act of 1662. Reproduced by permission of Houghton Library, Harvard University. A color version of this figure is available online.

Star Chamber decrees, injunctions of Elizabeth, edicts of Henry VIII, etc.). First, it required that all intended publications be registered with the government-approved Stationers' Company, thus giving the king his "royal prerogative" — and by extension, giving the Stationers the ultimate say in what got printed and what did not. With certain exceptions (such as government documents, bibles, and almanacs) "no private person or persons whatsoever shall att any time hereafter print or cause to be printed any Booke or Pamphlet whatsoever unlesse ... [it] be first 
entred in the Booke of the Register of the Company of Stationers of London." The number of London printing offices was restricted to twenty, as "no surer meanes can be advised" to control printing than limiting the number of presses. The king's representatives "shall have power and authority . . . to search all Houses and Shops" and confiscate whatever they deemed unlawful. Penalties by fine and imprisonment for offenders were decreed. Charles and his Parliament also weighed in on the importation of books, the appointment of licensers, and the number of printers and founders. The right to copy was yet another means of quashing the press. The person who registered a title with the Company — who might be a printer, a publisher, or an author — received this right. As the Act stated, "[Once printed, each book] shall be first lawfully licensed and authorized to be printed by such person and persons only as shall be constituted and appointed to license the same according to the direction and true meaning of this present Act."

Certainly, a tighter rein would eradicate all offending material. Or would it? Have today's copyright claims kept at bay the wholesale copying of books, the digitization of artwork, or people downloading music? Then it is not surprising to learn that the 1662 Act only met with partial success. One gets the sense that London in the late seventeenth century was a place where definitions of morality were highly subjective and authority was exercised in extremely uneven fashion. For example, despite regular attempts to number the presses to twenty, we know that far more were in operation in the years immediately following the Act's publication-perhaps as much as triple that number. Furthermore, despite the censors' utmost efforts, any number of seditious pamphlets were printed, pamphlets with such wonderfully evocative and enigmatic titles as The Panther Prophecy, Poore Robin, Mercurius Politicus, Smectymnuus Redivivus, and Ahab's Fall (see fig. 2).

On the heels of the Act, state activities as they related to copyright were assorted. ${ }^{1}$ As in today's attempts at legislation, there was a great deal of lobbying undertaken. For example, on July 2, 1663, the editor Thomas Stanley asked for and was granted copyright for twentyone years for the sole printing of his edition of Aeschylus's tragedies. A October 24, 1663, entry in the Calendar of State Papers records a "prohibition to any persons to copy or reprint, however disguised by alterations, the whole or part of Richard Daniel's book 'A Compendium of the usual Hands of England, Netherlands, France, Spain, etc.'” Both Stanley's and Daniel's appeals for copyright seem to have been respected. Heirs of deceased copyholders - both sons and widows - petitioned to keep their fathers' and spouses' copyrights, usually successfully. On March 3, 1663, the Calendar of State Papers records a "prohibition against any person printing, for five years, any portion of The history of the worthies of England, compiled by Dr. Thomas Fuller, except his son John Fuller." This, too, appears to have been successful: another edition of it did not appear until the nineteenth century. In early 1664, the publisher and printer Ann Seyle

1. The author is heavily indebted to Donald McKenzie and Maureen Bell's A Chronology and Calendar of Documents Relating to the London Book Trade, 1641-1700 (Oxford: Oxford University Press, 2005). The quotations that follow are all from this book; documents are listed in chronological order. 


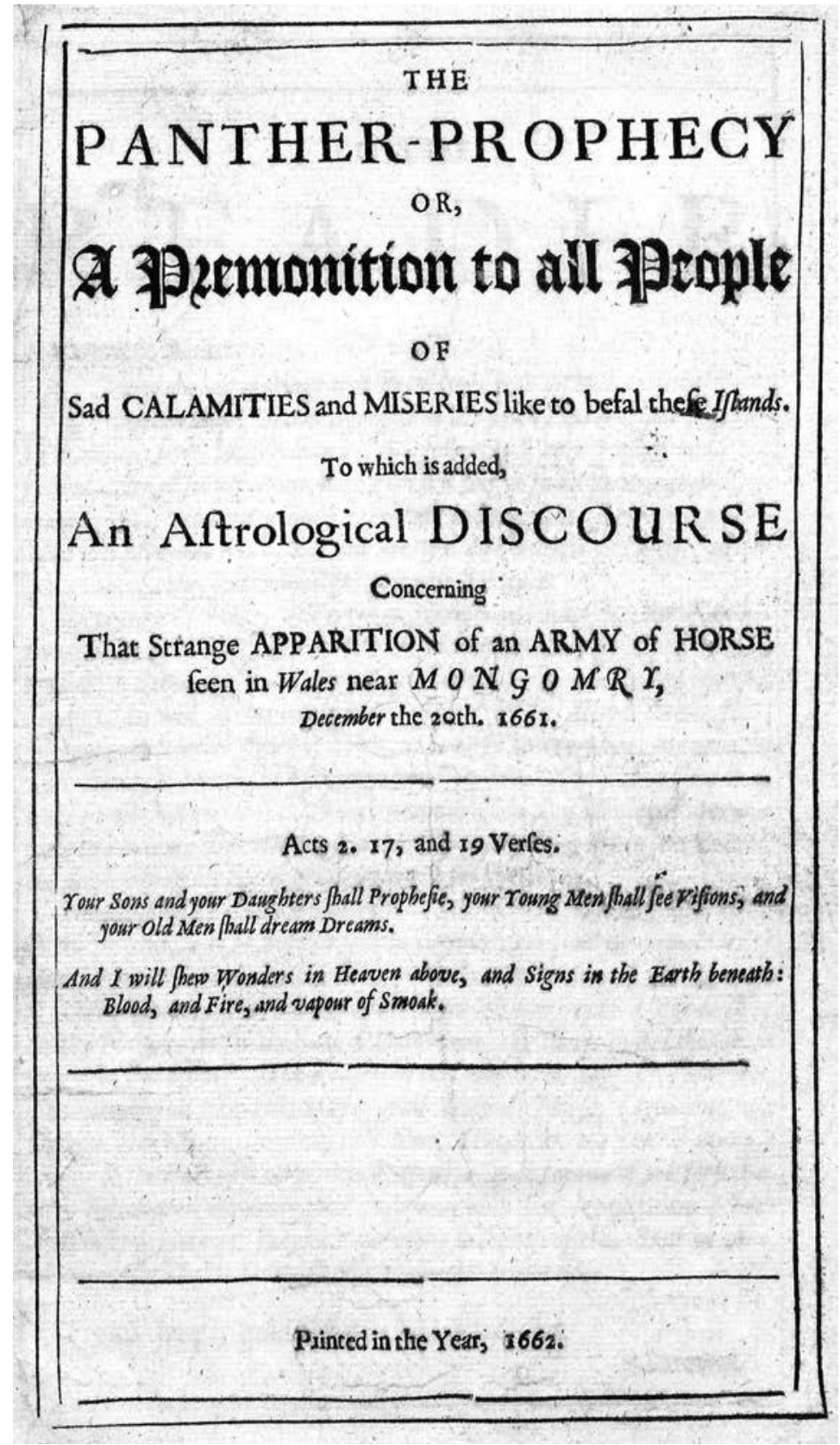

Figure 2. One of the many seditious pamphlets that the Act attempted to suppress. Reproduced by permission of Houghton Library, Harvard University. A color version of this figure is available online. 
petitioned the Company of Stationers for a copyright, "saying that her late husband bought Dr. Heylin's Cosmography from the Doctor himself and entered it for his copy in Stationers' Hall; he had been at great charge in printing it, and dying, left it to her and his children." Ann's edition appeared two years later; she - either independently or with partners - reissued it numerous times without competition for over a decade.

Others were less successful. On December 10, 1663, the Calendar of State Papers recorded "the petition of Sir Jos. Van Coulster and Charles Arundel for the sole license of printing all almanacs and books relating to astrology and astronomy, in which several abuses had been committed lately; the right of printing had always been inherent in the Crown." In response to the pirating of his extremely popular Hudibras, on November 24, 1663, Samuel Butler is given license "to print the second part of Hudibras, with a prohibition to all others against printing it." It didn't work; pirated editions continued to appear. Both the Universities at Oxford and Cambridge, albeit given certain privileges in the Act, are repeatedly targeted for printing material that is licensed elsewhere.

Scofflaws were hunted down. On January 21, 1662, Marmaduke Johnson (of Eliot Indian Bible fame) had his premises searched; removed was "[a run of] an Almanac called Poore Robin ... in diminucion to the Companys Title, to whome the sole Printing of all Almanacks by Charter [belonged]." On December 20, 1662, Samuel Speed was arrested for selling law books, for it was stated in the Act that "All Books concerning the Common Lawes of this Realm shall be printed by the special allowance of the Lord Chancellor or Lord Keeper of the Great Seal of England." Then, on August 15, 1663, Charles II appointed the royalist pamphleteer Roger L'Estrange licenser of the press (fig. 3). L'Estrange was already acting as a royalist spy, ultra-conservative mouthpiece, and unofficial attack dog. This new responsibility gave him full rein to search and confiscate any printed material deemed "treasonable and schismatical"-including unlicensed books. It also gave him license to print (with the exception of certain categories of material already licensed to the king's own printers and the Stationer's English stock) "all narratives or relations not exceeding two sheets of paper and all advertisements, mercuries, diurnals and books of public intelligence" (Siebert 1952, 292-93). L'Estrange was a very busy man in the 166os: state and Stationers' Company documents contain dozens of arrest warrants supplied to him. Not only were there treasonable and unlicensed materials to be confiscated, there were the shoemakers, haberdashers, and fishmongers who had to be apprehended for selling books. As the Act spelled out in no uncertain terms, "No Haberdasher of Small Wares Ironmonger Chandler Shopkeeper or other person or persons whatsoever not being licensed in that behalfe by the Lord Bishop of the Diocese ... shall within the City or Suburbs of London or any other Market Towne or elsewhere receive take or buy or barter sell againe change or doe away any Bibles Testaments Psalm books Common Prayer books Primers Abcees Licensed Almanacks Grammar School books or other Book or Books whatsoever upon pain of forfeiture of the same." 


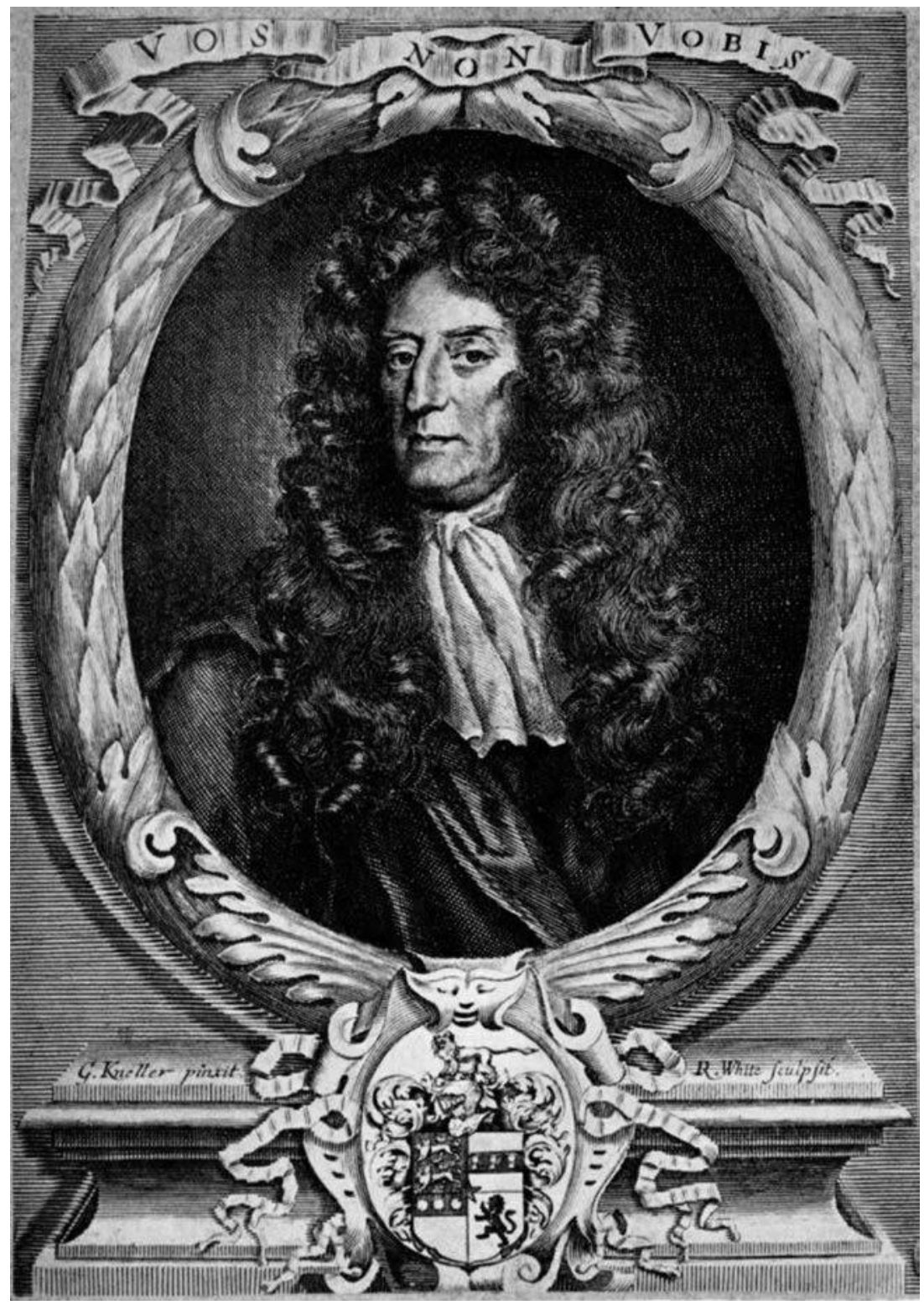

Figure 3. Roger L'Estrange, by Robert White, after Sir Godfrey Kneller, line engraving, published 1692. Reproduced by permission of Houghton Library, Harvard University. A color version of this figure is available online. 
The Calendar of State Papers and Stationers' Company documents register scores of events relating to "copy rights" in just the first year of the Act. This might sound troubling until one realizes that the English Short-Title Catalogue lists almost 1,500 imprints for that year-and that is no doubt a very conservative figure of total imprints (given our knowledge of how low survival rates were of popular titles and ephemera). In fact, far more unregistered titles than registered titles made their way into the marketplace. An irate Charles recognized this and, in order to continue his fight against the press, convinced Parliament to renew the two-year Act in 1665 . Through a regular scheme of increasingly draconian renewals, it was not until 1692 that it permanently lapsed. By then, the hue and cry over state censorship and the rights of the stationers and of an ever-increasing number of professional authors (including Defoe and Swift) had reached a critical mass. Parliament was petitioned for new censorship legislation, and in 1710 it passed "An Act for the Encouragement of Learning, by Vesting the Copies of Printed Books in the Authors or Purchasers of Copies, during the Times therein mentioned" (Statute of Anne, 1710, 8 Anne, c. 19; also see Deazley 2008b). The "Statute of Anne" is now recognized as the first Anglo-American copyright law. It took away the Stationers permanent title to copy and instead gave authors fourteen years of ownership (renewable for another fourteen years should the author still be alive). Authors still needed to register their works with the Stationers, but they controlled the rights to choose a publisher and copy their work. The restincluding what is happening in Washington right now—is history.

\section{References}

Deazley, Ronan. 2008a. “Commentary on the Licensing Act, 1662." In Primary Sources on Copyright (1450-1900), ed. Lionel Bently and Martin Kretschmer. Cambridge: University of Cambridge, Faculty of Law. http:// www.copyrighthistory.org.

Deazley, Ronan. 2008b. “Commentary on the Statute of Anne, 1710.” In Primary Sources on Copyright (14501900), ed. Lionel Bently and Martin Kretschmer. Cambridge: University of Cambridge, Faculty of Law. http://www.copyrighthistory.org.

Pallante, Maria A. 2013. "The Next Great Copyright Act." Columbia Journal of Law and the Arts 36 (3): 315-44. Siebert, F. S. 1952. Freedom of the Press in England, 1476-1776. Urbana: University of Illinois Press.

Karen Nipps: head of the Rare Book Team at Houghton Library, Harvard University. As the cover editor for Library Quarterly, she has written on a number of printers and their devices, ranging from Aldus Manutius in fifteenth-century Italy to William Rudge in twentieth-century America. She is the author of Lydia Bailey: A Checklist of Her Imprints (University Park: Pennsylvania State University Press, 2013). E-mail: nipps@fas.harvard.edu. 